\title{
Studies on Genetic Variability Parameters on Grain Yield and Its Yield Attributing Traits in Maize (Zea mays L.)
}

\author{
Arun Kumar Singh ${ }^{1 *}$, S.P. Mishra ${ }^{1}$ and Roshan Parihar $^{2}$
}

${ }^{1}$ Department of Crop Sciences, Faculty of Agriculture, Mahatma Gandhi Chitrakoot

Gramodaya Vishwavidyalaya, Chitrakoot, Satna - 485334 (M.P.), India

${ }^{2}$ Department of Genetics and Plant Breeding, B.T.C. College of Agriculture and Research

Station (IGKV, Raipur, C.G), Sarkanda, Bilaspur, Chhattisgarh-495001, India

*Corresponding author

\section{A B S T R A C T}

Maize (Zea mays L.), the American Indian word for corn, in Indian common name makka has various names in different part of world has its literal meaning "a product which sustains life". It mainly produced in temperate regions of the western hemisphere and

Key words

Maize (Zea mays

L.), Genetic

variability, Yield

Article Info

Accepted:

08 August 2018

Available Online:

10 September 2018
China; Brazil and several countries in Europe etc. Its production is mainly dominated by top five countries (US, China, Brazil, Mexico and Argentina) accounting for nearly $75 \%$ of the world production (Kumar, 2008). In the present study 20 diverse varieties/genotypes were grown in RBD design with three replications during Kharif 2015 to study the genetic parameters viz. ANOVA, GCV, PCV, h2 and Genetic Advance (GA). The results indicates that ANOVA for all the characters viz. cob weight, shelling $\%$, moisture $\%$, initial plant stand, final plant stand, cob count, days to $50 \%$ pollen shed, days to $50 \%$ silking, days to $70 \%$ dry husk, plant height, ear height are highly significant while grain yield showed significant values. The high GCV and PCV values were observed for grain yield, cob weight while moderate GCV and PCV values were shown by moisture \%, days to $70 \%$ dry husk and cob count. High heritability coupled with high expected genetic advance in per cent of mean was observed for grain yield, cob count, days to $70 \%$ dry husk, plant height, and ear height. Conclusively PCV was higher GCV indicates that environmental role in the expression of these traits.

\section{Introduction}

Maize (Zea mays L.), the American Indian word for corn, in Indian common name makka has various names in different part of world its literal meaning "a product which sustains life".

It mainly produced in temperate regions of the western hemisphere and China, Brazil and several countries in Europe etc. Its production is mainly dominated by top five countries (US, China, Brazil, Mexico and Argentina) accounts nearly $75 \%$ of the world production (Kumar, 2008). Its highest yield were obtained in industrialized countries such as France and the United states (both) $9.5 \mathrm{t} / \mathrm{ha}$ ), Canada (8.5t/ha), Argentina (7.5 t/ha), where the production is highly mechanized and based on well-developed crop cultivars, seed selection 
and adequate inputs, along with favourable climate(including irrigation) and soil conditions (Faostat, 2012).

Maize is the oldest cultivated crops no longer capable of survival in the wild form and can be grown only under cultivation. Maize (Zea mays L.) is the only species in the genus Zea, has its diploid chromosome number $2 \mathrm{n}=20$. Maize (Zea mays) an agronomically versatile crop in India after rice and wheat. The Success of any crop improvement or breeding program depends upon the selection of suitable parents, although knowledge of genetic variability, heritability and type of gene action is very essential. In addition, characters upon which selection of parent is based on should be known. Relatively higher estimates of genotype coefficient of variation for straw weight, grain weight, plant height, ear placement, kernel rows per ear, number of grains per row along with high heritability suggests that selection can be effective for these traits. Keeping this in view, the presented studies were under taken to study the genetic parameters of selected genotypes of maize the nature and magnitude of genetic variability, correlation and path coefficient analysis between different traits of maize genotypes with the following objectives to estimate the nature and magnitude of genetic variability, heritability and genetic advance for yield and yield components in maize genotypes.

\section{Materials and Methods}

The present investigation of experiment was conducted in a well prepared field during Rabi 2015-16 at Agriculture Farm, Nana Ji Deshmukh New Agriculture Campus, Mahatma Gandhi Chitrakoot Gramodaya Vishwavidyalaya, Chitrakoot, Satna (M. P.). A germplasm collection of 20 diverse varieties/genotypes viz. GYH-0656, AH9001, FH 3664, JH 31613, CMH 10-531, PMH-5-C,
Parkash-C, Siri -4527, HTMH 5202, DASMH-105， X35D601， DKC9133， IM8556, CP.999, PRO-392, DKC9141(MI8539), PMH1-C, PMH-3-C, Seed tech 2324-C, BIO9681$\mathrm{C}$ of Maize constituted the experimental materials comprised of early and late maturing genotypes for the present study. These genotypes were obtained from the Indian Institute of Maize Research, I.A.R.I. Campus, and New Delhi.

The Experiment was conducted to evaluate the twenty genotypes /varieties of maize under normal soil and rainfed condition. The experiment was laid out in Randomized Block Design (RBD) with three replications during Kharif 2015. The experiment was sown on $14^{\text {th }}$, July, 2015. Each treatment was grown in $4 \mathrm{~m}$ long X 6 rows per plot spaced $45 \mathrm{~cm}$ apart. The plant to plant distance was maintained $30 \mathrm{~cm}$ by thinning. Recommended agronomic practices and plant protection measures were adopted to raise a good crop. To take out the observations five competitive plants from each plot were randomly selected for recording of observations on 12 characters. viz. Cob Weight (kg), Shelling per cent, Moisture per cent, Initial plant stand, Final Plant Stand, Cob Count, Days to $50 \%$ pollen shed, Days to $50 \%$ silking, Days to $70 \%$ dry husk, Plant height $(\mathrm{cm})$, Ear height $(\mathrm{cm})$, Grain yield $(\mathrm{kg} / \mathrm{ha})$. The analysis of variance for the design of the experiment was carried out according to the procedure outlined by Panse and Sukhatme (1967). Heritability in broad sense $\left(h^{2}\right)$ was calculated using the formula suggested by Burton and de Vane (1953) and Genetic advance was calculated by the method suggested by Johnson et al., (1955).

\section{Results and Discussion}

Genetic potentiality of a genotype is measured not only by mean performance but also on the extent of variability. The magnitude of genotypic and phenotypic variability helps a 
breeder for formulating successful breeding programmes (Allard, 1960). The genetic advance indicates the progress that can be expected as result of exercising selection on the pertinent population. Heritability and genetic advance gives a reliable index of selection value (Johnson et al., 1955). Plant breeders commonly faced the problems during handling of segregating populations and selection procedures. Mean and variability are the important factors for selection. Mean serves as a basis for eliminating undesirable crosses or progenies. Variability helps to choose a potential cross or progeny since variability indicates the extent of recombination for initiating effective selection procedures. In the present investigation, analysis of variance, GCV, PCV, Heritability and genetic advance are discussed with different heads.

\section{Analysis of variance}

Analysis of variance for the design of the experiment characters indicated highly significant value for all the characters viz. cob weight, shelling $\%$,moisture $\%$, initial plant stand, final plant stand, cob count, days to $50 \%$ pollen shed, days to $50 \%$ silking, days to $70 \%$ dry husk, plant height, Ear height and except grain yield(kg per ha) showed significant. The mean sum of squares due to replications, treatments and error are presented in Table 1. Variance due to replication were found non- signification for all the parameters under study.

\section{Genetic variability studies}

The mean performances of genotypes for 12 characters with their general mean and range for all the traits, GCV,PCV,CV \% are presented in Table 2 . The genetic variability present in the germplasm provides the raw material for any plant breeding programme on which selection acts to evolve superior genotypes. Thus higher the amount of variation present for character in the breeding materials, greater is the scope for its improvement through selection.

The phenotypic and genotypic coefficient of variations were estimated to assess the existing variability and presented in Table 2. Indicates that high PCV \& GCV was shown by grain yield $(\mathrm{kg} / \mathrm{ha})$ with values 21.28 and 11.43 , respectively. Moderate values of PCV\& GCV are shown by Cob weight (13.98), (10.02) followed by moisture per cent (12.90), (8.18), cob count values (9.22), (8.77), days to $70 \%$ dry husk showed values (9.95), (9.21) and ear height (8.29) (7.11) respectively.

Whereas low values of PCV\& GCV are exhibited by shelling per cent (6.10) and (4.86) followed by initial plant stand (3.79), (3.17), final plant stand (4.80), (3.94), Days to $50 \%$ pollen shed (6.58), (5.17). Days to 50\% silking (7.75), (5.08) and plant height (7.23), (4.82). In general the phenotypic coefficient of variability $(\mathrm{PCV})$ was higher than genotypic coefficients of variability (GCV) indicates the environment influence considerably in expression of these traits. The similar results were reported by Mansir Yusuf, (2010), (Singh and Narayana, 2000), Devi, et al., (2013) and Ghosh, et al., (2014).

\section{Heritability and genetic advance}

Heritability estimate, that provides the assessment amount of transmissible genetic variability to total variability, happens to be most important basic factor that determines the genetic improvement or response to selection. Heritability and genetic advance values are presented in Table 3. However, the degree of improvement attained through selection is not only dependent on heritability but also on the amount of genetic variation present in the breeding material and extent of selection procedure applied by the breeder. 
Table.1 Analysis of variance for twelve quantitative characters in Maize

\begin{tabular}{|c|c|c|c|c|}
\hline \multirow[t]{3}{*}{ S. No. } & \multirow[t]{2}{*}{ Characters } & \multicolumn{3}{|c|}{ Mean Sum of Squares } \\
\hline & & Replication & Treatments & Error \\
\hline & d.f. & 2 & 19 & 38 \\
\hline 1 & Cob wt (Kg) & 8.02 & $14.84 * * *$ & 3.56 \\
\hline 2 & Shelling \% & 9.66 & $59.98 * * *$ & 9.66 \\
\hline 3 & Moisture\% & 4.14 & $11.86^{* *}$ & 3.93 \\
\hline 4 & Initial Plant Stand & 4.38 & $41.72 * * *$ & 5.23 \\
\hline 5 & Final Plant Stand & 5.41 & $56.76 * * *$ & 7.86 \\
\hline 6 & Cob count & 2.53 & $258.51 * * *$ & 8.79 \\
\hline 7 & Day to $50 \%$ Pollen Shed & 10.29 & $22.88 * * *$ & 3.91 \\
\hline 8 & Day to $50 \%$ silking & 4.55 & $34.02 * * *$ & 10.43 \\
\hline 9 & Day to $70 \%$ dry husk & 14.56 & $242.75 * * *$ & 12.84 \\
\hline 10 & Plant Ht $(\mathrm{cm})$ & 28.38 & $444.99 * * *$ & 130.94 \\
\hline 11 & Ear Ht. (cm) & 16.13 & $118.19 * * *$ & 12.70 \\
\hline 12 & Grain yield (kg/ha) & 10546.61 & $49479.00 *$ & 22322.55 \\
\hline
\end{tabular}

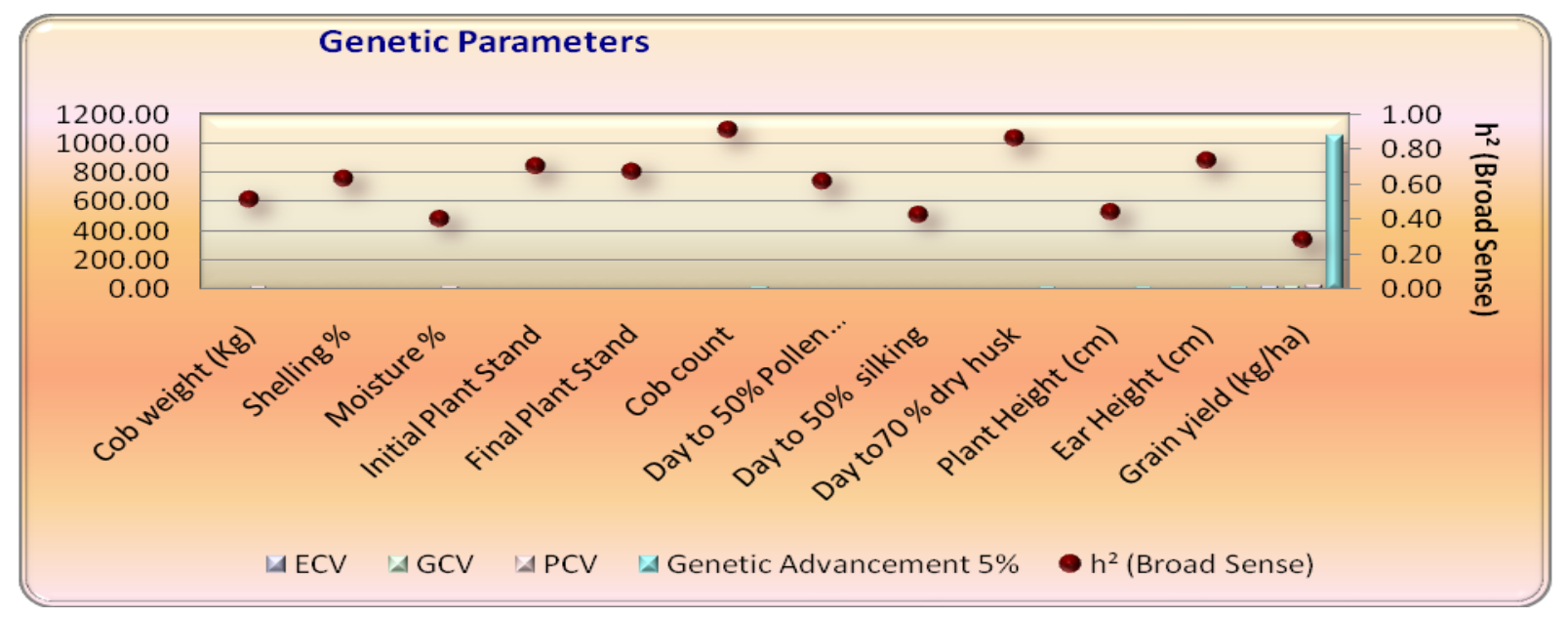

Table.2 Mean, range, genotypic, phenotypic and coefficient of variation for 12 quantitative characters in Maize

\begin{tabular}{|c|c|c|c|c|c|c|c|}
\hline \multirow[b]{2}{*}{$\begin{array}{l}\text { S. } \\
\text { No. }\end{array}$} & \multirow[b]{2}{*}{ Characters } & \multirow[b]{2}{*}{$\begin{array}{c}\text { Grand mean } \\
(\mathbf{X})+\mathrm{SE}(\mathrm{m})\end{array}$} & \multicolumn{2}{|c|}{ Range } & \multicolumn{2}{|c|}{$\begin{array}{c}\text { Coefficient of } \\
\text { Variation }\end{array}$} & \multirow[b]{2}{*}{ C.V.(\%) } \\
\hline & & & Min. & Max. & GVC & PCV & \\
\hline 1 & Cob wt (Kg) & $19.35 \pm 1.09$ & 15.04 & 23.53 & 10.02 & 13.98 & 9.75 \\
\hline 2 & Shelling \% & $84.22 \pm 1.79$ & 75.86 & 91.33 & 4.86 & 6.10 & 3.69 \\
\hline 3 & Moisture \% & $19.87 \pm 1.14$ & 16.70 & 23.13 & 8.18 & 12.90 & 9.97 \\
\hline 4 & Initial Plant Stand & $109.94 \pm 1.32$ & 105.00 & 115.62 & 3.17 & 3.79 & 2.08 \\
\hline 5 & Final Plant Stand & $102.34 \pm 1.62$ & 96.33 & 111.44 & 3.94 & 4.80 & 2.74 \\
\hline 6 & Cob count & $104.04 \pm 1.71$ & 78.29 & 116.00 & 8.77 & 9.22 & 2.85 \\
\hline 7 & Day to $50 \%$ Pollen Shed & $48.63 \pm 1.14$ & 44.67 & 57.07 & 5.17 & 6.58 & 4.07 \\
\hline 8 & Day to $50 \%$ silking & $55.15 \pm 1.86$ & 47.67 & 63.00 & 5.08 & 7.75 & 5.86 \\
\hline 9 & Day to $70 \%$ dry husk & $95.03 \pm 2.07$ & 80.67 & 105.67 & 9.21 & 9.95 & 3.77 \\
\hline 10 & Plant Ht (cm) & $212.42 \pm 6.61$ & 194.67 & 233 & 4.82 & 7.23 & 5.39 \\
\hline 11 & Ear Ht. (cm) & $83.42 \pm 2.06$ & 73.67 & 90.67 & 7.11 & 8.29 & 4.27 \\
\hline 12 & Grain yield (kg/ha) & $8322.23 \pm 862.60$ & 6335.99 & 10422.26 & 11.43 & 21.28 & 17.95 \\
\hline
\end{tabular}




\begin{tabular}{|c|c|c|c|c|}
\hline $\begin{array}{l}\text { S. } \\
\text { No. }\end{array}$ & Characters/Traits & $\begin{array}{c}\text { Heritability (broad } \\
\text { sense) }\end{array}$ & Genetic advance & $\begin{array}{c}\text { Genetic advance } \\
\text { as \% of mean }\end{array}$ \\
\hline 1. & Cob wt $(\mathrm{Kg})$ & 51.37 & 2.86 & 14.79 \\
\hline 2 & Shelling $\%$ & 63.45 & 6.72 & 7.98 \\
\hline 3 & Moisture\% & 40.23 & 2.12 & 10.69 \\
\hline 4 & Initial Plant Stand & 69.64 & 6.01 & 6.47 \\
\hline 5 & Final Plant Stand & 67.47 & 6.83 & 6.68 \\
\hline 6 & Cob count & 90.45 & 17.87 & 17.18 \\
\hline 7 & Day to $50 \%$ Pollen Shed & 61.78 & 4.07 & 8.37 \\
\hline 8 & Day to $50 \%$ silking & 42.99 & 3.79 & 6.87 \\
\hline 9 & Day to $70 \%$ dry husk & 85.65 & 16.69 & 17.56 \\
\hline 10 & Plant $\mathrm{Ht}(\mathrm{cm})$ & 44.43 & 14.05 & 6.61 \\
\hline 11 & Ear Ht. (cm) & 73.46 & 10.47 & 12.55 \\
\hline 12 & Grain yield $(\mathrm{kg} / \mathrm{ha})$ & 28.85 & 1052.76 & 12.65 \\
\hline
\end{tabular}

The parameter, genetic advance in per cent of mean (GAM) is a more reliable index for understanding the effectiveness of selection in improving the traits because its estimate is derived by involvement of heritability, phenotypic standard deviation and intensity of selection. Thus, heritability and genetic advance in per cent of mean, in combination, provide clear picture regarding the effectiveness of selection for improving the plant characters.

The results revealed that heritability in broad sense values were ranged from 28.85 per cent for grain yield to 90.45 for cob count. High heritability estimates were found for cob count (90.45) and days to $70 \%$ dry husk (85.65), The moderate heritability estimates were found for ear height(73.46), initial plant stand (69.64), final plant stand (67.47), shelling \% (63.45), days to $50 \%$ pollen shed (61.78) and cob weight (51.37) while low estimates were found for remaining characters viz. plant height (44.43), days to $50 \%$ silking (42.99), moisture \% (40.23) and grain yield (28.85) characters.

The expected genetic advance in per cent of mean ranged from 6.47 per cent for initial plant stand to 17.56 per cent for cob count. High estimates of expected genetic advance $\%$ of mean values were found for days to $70 \%$ dry husk (17.56) and cob count (17.18) followed by cob weight (14.79), grain yield (12.65), ear height (10.47) and moisture\% (10.69) while low expected genetic advance were found for days to $50 \%$ pollen shed (8.37), shelling \% (7.98), days to $50 \%$ silking (6.87), final plant stand (6.68), plant height (6.61) and initial plant stand (6.47).

High heritability coupled with high expected genetic advance in per cent of mean was observed for grain yield, cob count, days to $70 \%$ dry husk, plant height, and ear height. These findings was found in agreement with the result of Singh (1990), Mahmood, et al., (2004) for grain yield, Mangi et al., 2008), Ahmed et al., 2007)for. high heritability value and low genetic advance, Reddy, et al., (2013) for ear height, grain yield per plant, plant height, number of kernels per row and ear length, Nzuve, et al., (2014) for ear height and plant height and Reddy et al., (2016).

\section{Acknowledgement}

First author acknowledge, Mahatma Gandhi Chitrakoot Gramodaya Vishwavidyalaya, Chitrakoot, Satna (M. P.for providing field and financial support during the course of his thesis research experiment.

\section{References}

Ahmed, N., M.A. Chowdhry, I. Khaliq, and M. Maekaw, (2007). The inheritance of yield and yield components of five wheat 
hybrid populations under drought conditions. Indonesian J.Agri.Sci. 8(2):53-59.

Allard. R.W., 1960. Principle of plant breeding. John Wiley and Sons. New York.

Burton, G.W. and De Vane, E.H. (1953). Estimating heritability in tall fascue (Fastuca arundinacea) from replicated clonal material. Agron. J., 45: 478-481.

Devi, H. Nanita, Devi, K. Nandini, Singh, N. Brajendra, Singh, T. Ratan, Jyotsna, N. and Paul, Amitava (2013)Phenotypic Characterization, Genetic Variability and Correlation Studies among Maize Landraces of Manipur. International Journal of Bio-resource and Stress Management, 4(2) spe: 352-355

FAOSTAT data, 2012. Food and Agriculture organization statistics. http://faostat.fao. org. Accessed in 2012.

Ghosh Aditi, Subba Vaskar, Roy Anindita, Ghosh Amitava and Kundagrami Sabyasachi (2014) Genetic Variability and Character Association of Grain Yield Components in Some Inbred Lines of Maize (Zea mays L.) Journal of Agroecology and Natural Resource Management, 1(2): 34-39.

Johnson, H.W., Robinson, H.F. and Comstock, R.E., (1955). Estimates of genetic and environmental variability in soybeans. Agron. J. 47: 314-318.

Kumar (2008). Stability analysis of maize (Zea mays L.) in bred lines /introductions for yield parameters. Department of Genetics and plant breeding college of Agriculture, DHARWAD, University of Agricultural Sciences, DHARWAD-580 005. August, 2008.

Mahmood, Zahid, Ajmal, Saif Ullah, Jilani, Ghulam, Irfan, Muhammad and Ashraf,
Muhammad (2004)Genetic Studies for High Yield of Maize in Chitral Valley, Int. J. Agri. Biol., 6, (5): 788-789.

Mangi, S.A., M.A. Sial, B.A. Ansari and M.A. Arain, 2008. Study of genetic parameters in segregating populations of spring wheat. Pakistan J. Bot. 39(7): 2407-2413.

Mansir Yusuf (2010). Genetic variability and correlation in single cross hybrids of quality protein maize (Zea mays L.) 10. No.2

Nzuve, F., Githiri, S., Mukunya, D. M. \& Gethi J. (2014). Genetic Variability and Correlation Studies of Grain Yield and Related Agronomic Traits in Maize. Journal of Agricultural Science; 6(9); 166-176.

Panse, V.G. and Sukhatme, P.V. (1967). Statistical methods for Agricultural workers. ICAR, New Delhi.

Reddy, V. Ram and Jabeen, F. (2016). Narrow Sense Heritability, Correlation and Path Analysis in Maize (Zea Mays L.) SABRAO Journal of Breeding and Genetics, 48 (2): 120-126.

Reddy, V. Ram, Jabeen, Farzana, Sudarshan, M.R. and Rao, A. Seshagiri (2013) Studies on Genetic Variability, Heritability, Correlation and Path Analysis in Maize (Zea Mays L.) Over Locations. International Journal of Applied Biology and Pharmaceutical Technology, 4(1):195-199.

Singh, B. D. and Narayana, 2000. Plant Breeding: Interrelationships between yield and yield components in mung bean, Indian J. Genet. Plant breed, 30: 244-250.

Singh, B. D., 1990. Plant Breeding: principles Kalyani publishers, New Delhi, India. 506P.62.

\section{How to cite this article:}

Arun Kumar Singh, S.P. Mishra and Roshan Parihar. 2018. Studies on Genetic Variability Parameters on Grain Yield and Its Yield Attributing Traits in Maize (Zea mays L.). Int.J.Curr.Microbiol.App.Sci. 7(09): 1261-1266. doi: https://doi.org/10.20546/ijcmas.2018.709.150 